\title{
Drinking Water Security in the Mid-hill Region of Nepal
}

\author{
Durga D. Poudel ${ }^{1}$, Timothy W. Duex ${ }^{2}$ Roshan Poudel ${ }^{3}$ \\ ${ }^{1}$ Environmental Science Program, School of Geosciences, University of Louisiana at Lafayette, Lafayette, Louisiana, USA. \\ ${ }^{2}$ Geology, School of Geosciences, University of Louisiana at Lafayette, Lafayette, Louisiana, USA. \\ ${ }^{3}$ New York University School of Medicine, New York, USA.
}

\begin{abstract}
Drinking water security is increasingly becoming a global concern in recent decades. The mid-hill region of Nepal is also experiencing serious water shortages in recent years. In order to assess the availability of drinking water in the mid-hill regions of Nepal, we studied hydrogeology, land use types and collected water samples from 30 springs in Kavre, Kahmandu Valley, Nuwakot and Tanahu in Nepal between July 17-September 12, 2017. For each sampling spring, while surrounding land use type (mixed, agriculture, urban, vegetation) and spring type (fracture, depression, contact) were determined through field observation, the field $\mathrm{pH}$, conductivity and temperature was determined using relevant probes and thermometers. Water samples were collected in $1 \mathrm{~L}$ and $165 \mathrm{~mL}$ plastic bottles for chemical and total coliform determination, respectively, in the lab. Bottles were rinsed twice using spring water before filling them with sample water, then stored in an ice chest, and brought to the lab. In the laboratory, turbidity, conductivity, $\mathrm{Ca}, \mathrm{Mg}, \mathrm{HCO}, \mathrm{SO} 4, \mathrm{Na}, \mathrm{NO}, \mathrm{Cl}, \mathrm{Fe}, \mathrm{As}$, and total coliform were determined using standard methods. Spring water in agricultural areas showed significantly higher suspended solids compared to other land use types whereas spring water in urban areas showed significantly higher dissolved substances. By spring type, turbidity and conductivity values and the concentration of dissolved constituents $(\mathrm{Ca}, \mathrm{Mg}, \mathrm{HCO3}, \mathrm{SO} 4$, $\mathrm{NO3}$, and $\mathrm{Cl}$ ) were ranked in the order of fracture < contact < depression. Na and Fe concentration were in the order of fracture $=$ contact $<$ depression. By land-use type, conductivity and dissolved constituents $(\mathrm{Ca}, \mathrm{Mg}, \mathrm{HCO})$ were in the order of agriculture $<$ vegetation $<$ mixed $<$ urban. Whereas urban land use had the highest values for $\mathrm{SO} 4, \mathrm{Na}, \mathrm{NO3}$, and $\mathrm{Cl}$, other land use types showed variable order. Fe concentration was ranked in the order of urban $<$ mixed $<$ vegetation $<$ agriculture. Total coliform was in the order of mixed < agriculture $<$ urban $<$ vegetation. These results indicate that land use type and surface condition, which is possibly associated with human activities, heavily affect spring water properties in the region. These results suggest that drinking water security of mid-hill region of Nepal is threatened heavily due to poor spring water quality. Protection of drinking water sources should be specific to land use type and activities around the springs. Index Terms - three to six pertinent, specific
\end{abstract}

ASEJ - Scientific Journal of Bielsko-Biala School of Finance and Law

Volume 24, No 1 (2020), 5 pages

DOI: $10.5604 / 01.3001 .0014 .1351$

Received: 06 April 2020; Accepted: 15 April 2020 to the paper, keywords added after the abstract, separated by commas.

Index Terms - Spring water, Land Use, Water Quality, Water Security, Nepal

\section{INTRODUCTION}

Natural springs are the primary sources of drinking water in the mid-hill region of Nepal. Historically, settlements in the region are developed nearby the spring water sources. Communities utilize springs in many different ways such as by digging shallow wells, building reservoirs, using pipes to carry spring waters to settlement areas, or collecting water directly from the springs. Due to population increase, land use changes, economic development, and climate change, drinking water supply in recent years has become increasingly difficult in the mid-hill region of Nepal (Merz et al., 2003; Poudel and Duex, 2017). Poudel and Duex (2017) reported $12.2 \%$ of springs dried up in an agricultural watershed in the past ten years and remaining $73.2 \%$ of springs have decreased flow. Similarly, ICIMOD (2015) reported 15 to $30 \%$ of springs dried up in the past ten years in other watersheds in the region. Because of the springs dry up, local communities in rural areas are leaving their villages abandoning their ancestral properties behind. Declining drinking water availability is adversely affecting the socio-economic vitality of the region. Problem created by declining availability of spring drinking water is exacerbated by increasing water pollution.

Drinking water pollution from various sources including sewage lines, septic tanks, open pit toilets, agricultural activities, industries, and waste disposal threatens public health safety. Drinking water pollution has become a major environmental and public health problem in recent years throughout Nepal (Poudel and Duex 2017; Vaidya and Labh, 2017). While drinking water sources include surface water, ground water and even atmospheric water (e.g. rainwater,

Regular research paper: Published 30 April 2020

Corresponding author's e-mail: ddpoudel@gmail.com

Copyright $(C) 2018$ This is an open access article distributed under the Creative Commons Attribution CC-BY-NC 4.0 License. 
snow), spring water is the main source of drinking water in many parts of Nepal (Vaidya and Labh 2017). Some springs are used at their origin for drinking water while other springs are connected with a network of pipes for drinking water supply downstream. Polluted drinking water caused by elevated suspended sediment and fecal coliform counts, as well as other contaminants, has been reported by several researchers in the region (Warner et. al., 2008; Poudel and Duex 2017; Corwin et al. 2019).

Drinking water quality is evaluated using several standard physical, chemical and biological characteristics including, color, temperature, turbidity, taste, suspended solids, odor, fecal coliforms, $\mathrm{pH}$, biological oxygen demand, hardness, and various chemical constituents including $\mathrm{N}, \mathrm{P}, \mathrm{K}, \mathrm{Ca}, \mathrm{Mg}, \mathrm{Fe}$, and heavy metals (Warner et al. 2008; Vaidya and Labh 2017). According to the Ministry of Physical Planning and Works in the Government of Nepal, (2005), Nepal's National Drinking Water Quality Standards include the minimum and maximum limits, respectively, for the following: $\mathrm{pH} 6.5$ and 8.5; $\mathrm{Fe} 0.3$ and $3 \mathrm{mg} / \mathrm{l} ; \mathrm{Fl} 0.5$ and $1.5 \mathrm{mg} / \mathrm{l}$; and residual $\mathrm{Cl} 0.1$ and 0.2 $\mathrm{mg} / \mathrm{l}$. Similarly, maximum concentration limits expressed as a recommended range include 5 to 10 NTU for turbidity and 5 to $15 \mathrm{TCU}$ for color, respectively. Total dissolved solids and total hardness have maximum concentration limits of $1000 \mathrm{mg} / \mathrm{l}$ and $500 \mathrm{mg} / \mathrm{l}$, respectively. Maximum limit set for electrical conductivity is $1500 \mu \mathrm{S} / \mathrm{cm}$. Maximum concentration limits for As, Cl, SO4, NO3, and Ca were $0.05 \mathrm{mg} / 1,250 \mathrm{mg} / 1,250 \mathrm{mg} / \mathrm{l}$, $50 \mathrm{mg} / \mathrm{l}, 200 \mathrm{mg} / \mathrm{l}$ respectively. Maximum limit for total fecal coliform is $0 \mathrm{MPN} / 100 \mathrm{ml}$ for $95 \%$ sample and $0 \mathrm{MPN} / 100 \mathrm{ml}$ for E-coli.

The chemical, physical and biological properties of drinking water are affected by several factors including geology, climate, local environment, and atmospheric conditions. Therefore, an understanding of the relationship between natural factors such as land use types, hydrogeology, and drinking water quality is necessary for better management of spring water sources and for enhancement drinking water quality and water security. This study was conducted to visually assess the conditions of springs for drinking water supply and to understand the relationships between hydrogeology, land use types and drinking water quality in the mid-hill region of Nepal.

\section{MATERIALS AND METHODS}

A total of 30 spring water samples were collected from five districts (Kavre, Kathmandu, Lalitpur, Nuwakot, and Tanahu) in the mid-hill region of Nepal (Fig. 1) between July 17 September 12, 2017.

Table 1 presents the specific location and other relevant properties such as elevation, land use type, and spring type for each of the sampling sites.

FIGURE 1. WATER QUALITY SAMPLING LOCATIONS AND NUMBER OF SPRING WATER SAMPLES COLLECTED

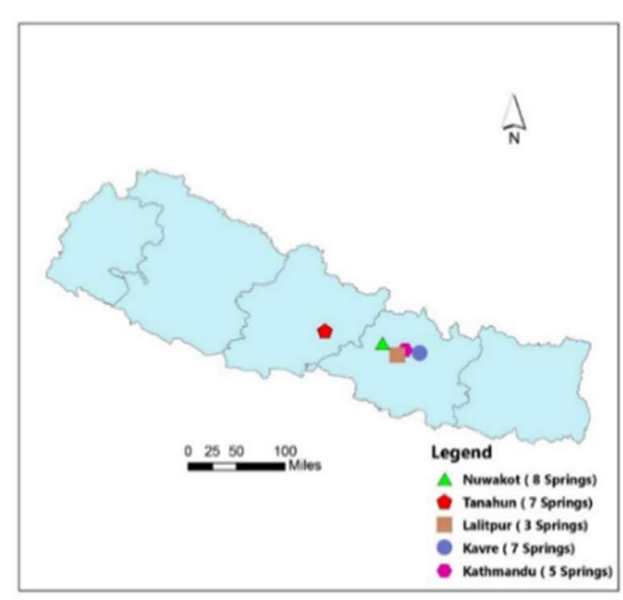

Source: prepared by the co-authors of this article

TABLE 1. SPRING WATER QUALITY SAMPLING LOCATIONS, SURROUNDING LAND USE AND SPRING TYPE IN KATHMANDU, LALITPUR, TANAHU, NUWAKOT, AND KAVRE DISTRICTS IN NEPAL

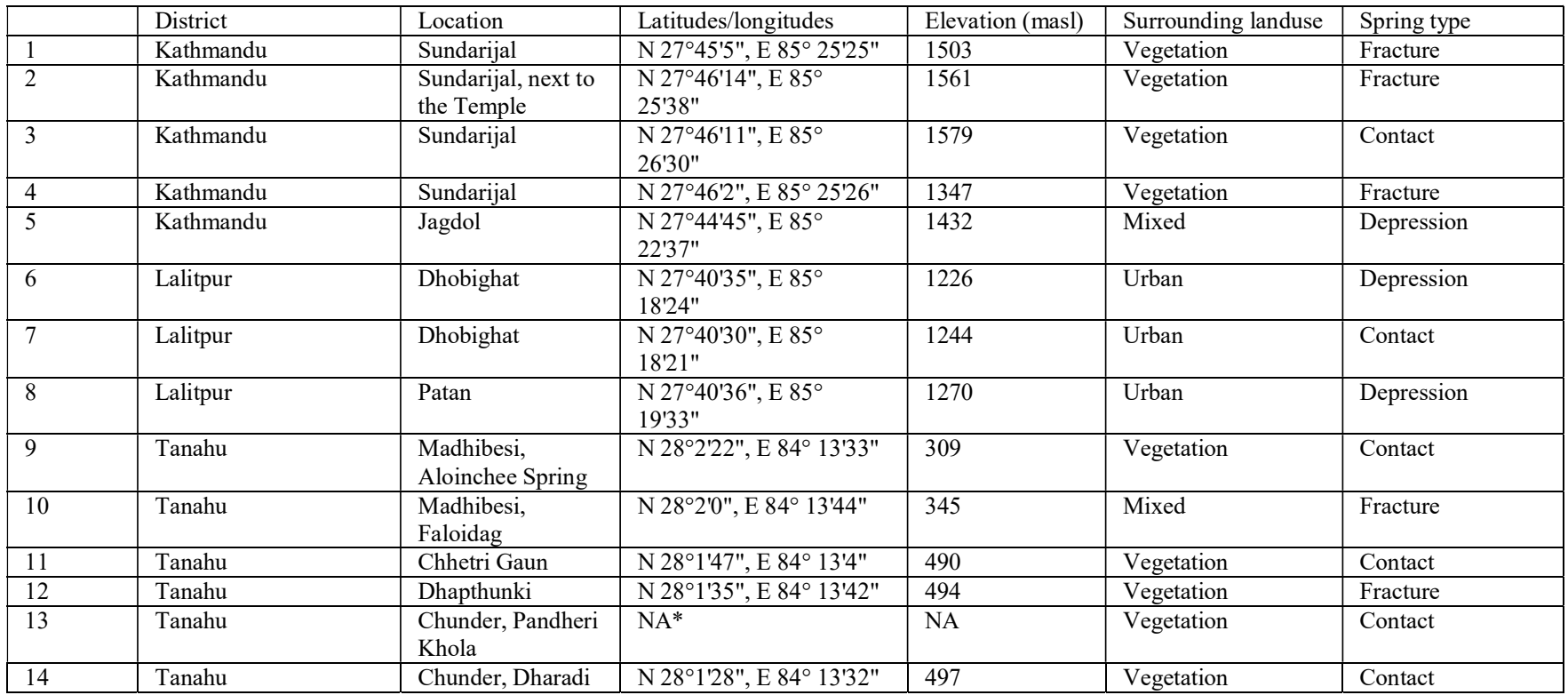




\begin{tabular}{|c|c|c|c|c|c|c|}
\hline 15 & Tanahu & $\begin{array}{l}\text { Sange, Dunde } \\
\text { Khola Spring }\end{array}$ & $\mathrm{N} 28^{\circ} 1^{\prime} 45^{\prime \prime}, \mathrm{E} 84^{\circ} 13^{\prime} 20^{\prime \prime}$ & 380 & Vegetation & Contact \\
\hline 16 & Nuwakot & Thulo Khola & N 275'ㅇ" & 524 & Vegetation & Depression \\
\hline 17 & Nuwakot & Thulo Khola & NA & NA & Agriculture & Depression \\
\hline 18 & Nuwakot & Thulo Khola & N 275ㄴ' $2^{\prime \prime}$, E $85^{\circ} 5^{\prime} 7^{\prime \prime}$ & 555 & Vegetation & Contact \\
\hline 19 & Nuwakot & Thulo Khola & N 2750'56", E 85 5'16" & 589 & Vegetation & Fracture \\
\hline 20 & Nuwakot & Thulo Khola & 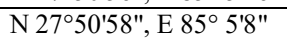 & 537 & Vegetation & Contact \\
\hline 21 & Nuwakot & Thulo Khola & NA & NA & Agriculture & Depression \\
\hline 22 & Nuwakot & Thulo Khola & NA & NA & Agriculture & Contact \\
\hline 24 & Kavre & Kantitar & $\begin{array}{l}\text { N } 27^{\circ} 42^{\prime} 42^{\prime \prime}, \text { E } 85^{\circ} \\
38^{\prime} 27^{\prime \prime}\end{array}$ & 729 & Vegetation & Contact \\
\hline 25 & Kavre & Amghave & 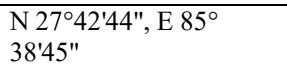 & 777 & Mixed & Depression \\
\hline 26 & Kavre & Kuntabesi & N 274' $6^{\prime \prime}$, E $85^{\circ} 36^{\prime} 37^{\prime \prime}$ & 816 & Vegetation & Contact \\
\hline 27 & Kavre & Kantitar & $\begin{array}{l}\text { N } 27^{\circ} 42^{\prime} 42^{\prime \prime}, \text { E } 85^{\circ} \\
38^{\prime} 27^{\prime \prime}\end{array}$ & 729 & Vegetation & Contact \\
\hline 28 & Kavre & Kuntabesi & $\begin{array}{l}\text { N } 27^{\circ} 42^{\prime} 50^{\prime \prime}, \text { E } 85^{\circ} \\
36^{\prime} 52^{\prime \prime}\end{array}$ & 795 & Urban & Depression \\
\hline 29 & Kavre & Dhulikhel & $\begin{array}{l}\text { N } 27^{\circ} 37^{\prime} 10^{\prime \prime}, \text { E } 85^{\circ} \\
34^{\prime} 17^{\prime \prime}\end{array}$ & 1373 & Vegetation & Contact \\
\hline 30 & Kavre & Dhulikhel & 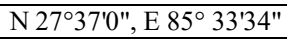 & 1421 & Vegetation & Fracture \\
\hline
\end{tabular}

* NA $=$ Not available.

Source: prepared by the co-authors of this article

Four land use types found around the springs include: agriculture, vegetation, mixed and urban area. While "Vegetation" land use included mainly forest and shrub lands, "Agriculture" land use type included mainly rice paddies. The "Mixed" land use type included forest, shrub lands and agricultural areas. The "Urban" land use type was mainly in developed areas. Elevation of the sampling sites, expressed as meters above sea level (masl), ranged from 309 masl to 1579 masl with an average elevation of 872 masl.

The spring samples were collected in a variety of places ranging from valley floors to hill slopes. The districts of Kavre and Tanahu had seven water samples each, the district of Nuwakot had eight samples, and the districts of Kathmandu and Lalitpur had five and three samples, respectively. Spring water samples were collected as close to the spring origin as possible (Photo 1).

In cases where the spring origin was inaccessible, the samples were collected downstream or via pipes installed by locals to access the spring water.

The locations and pictures of each sample collection location were entered using Open Data Kit (ODK) data collection. ODK was used to determine the coordinates and altitude of each location. The surrounding land use type (mixed, agriculture, urban, vegetation) and spring characterization (fracture, depression, contact) were based on geomorphology and were logged into a field journal. Field measurements of the water samples were taken using a field test kit and thermometer. The field measurements for $\mathrm{pH}$ and conductivity of each sample were taken by dipping the test kit's probes for $\mathrm{pH}$ and conductivity into a $100 \mathrm{ml}$ beaker filled with the spring water. A mercury thermometer was used to measure the water temperature.

Two plastic bottles were used for sample collection from each sample site. A larger, 1L bottle was used to collect samples for chemical tests, whereas a smaller, $165 \mathrm{~mL}$ bottle was used to collect samples for bacteriological testing. All bottles were carefully rinsed two times using water from the spring before they were filled with the spring water. PHOTO 1. WATER QUALITY SAMPLING AND FIELD
MEASUREMENTS

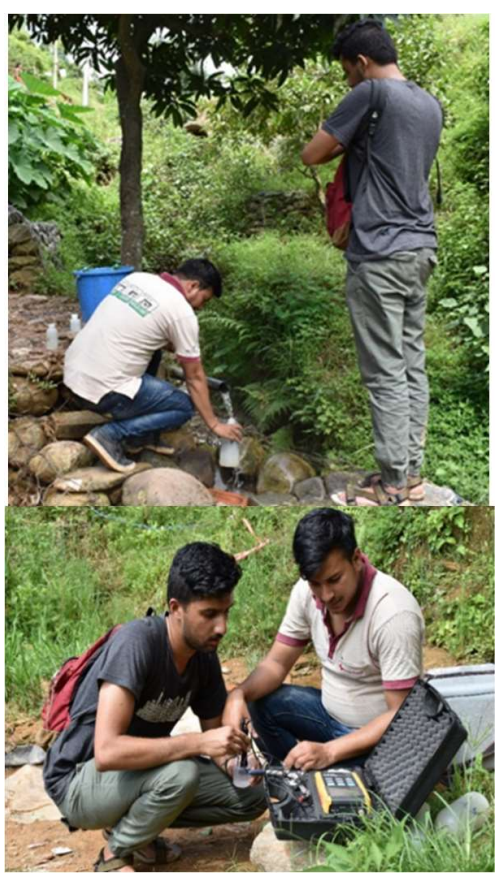

Source: taken by the co-authors of this article

The samples were stored in an ice chest and transported to the lab for testing. In the laboratory, turbidity, conductivity, $\mathrm{Ca}$, $\mathrm{Mg}, \mathrm{HCO} 3, \mathrm{SO} 4, \mathrm{Na}, \mathrm{NO} 3, \mathrm{Cl}, \mathrm{Fe}$, As, and total coliform were determined using standard methods (Clesceri et al. 1998).

\section{RESULTS AND DISCUSSION}

A simple comparison of the physicochemical and biological properties of drinking water samples and Nepal's National Drinking Water Quality Standards showed that none of the water samples analyzed exceeded the maximum concentration limits of $200 \mathrm{mg} / 1$ for $\mathrm{Ca}, 250 \mathrm{mg} / 1$ for SO 4 , and $0.05 \mathrm{mg} / 1$ for As. Similarly, all samples had conductivity values within the 
threshold limits of $1500 \mu \mathrm{S} / \mathrm{cm}$. Only two samples exceeded maximum concentration limit of NO3 of $50 \mathrm{mg} / \mathrm{l}$. These two samples with NO3 concentration of $64.2 \mathrm{mg} / \mathrm{l}$ and $117.8 \mathrm{mg} / \mathrm{l}$ came from the urban areas of Lalitpur district. In regard to $\mathrm{Fe}$ concentrations, 26 samples had $<0.3 \mathrm{mg} / \mathrm{l} \mathrm{Fe}$, while one sample from Nuwakot showed $3.7 \mathrm{mg} / \mathrm{l} \mathrm{Fe}$ and the remaining three samples had $0.57 \mathrm{mg} / 1,0.61 \mathrm{mg} / 1$ and $0.71 \mathrm{mg} / \mathrm{l} \mathrm{Fe}$. The standard maximum concentration limit for $\mathrm{Fe}$ in drinking water is $0.3 \mathrm{mg} / \mathrm{l}$. Turbidity values ranged from 1 to $90 \mathrm{NTU}$ with $16 \%$ of the samples exceeding the recommended upper range limit of 10 NTU. The $\mathrm{pH}$ values ranged from 5.9 to 7.4 with $23 \%$ of the samples less than the standard lower $\mathrm{pH}$ limit of 6.5 . Total coliform values ranged from 4 to $>300 \mathrm{MPN} / 100 \mathrm{ml}$. Seventy percent of the samples showed $>300 \mathrm{MPN} / 100 \mathrm{ml}$ of total coliform suggesting that most drinking water sources were heavily polluted with bacteria. Range and average concentrations of physicochemical and biological properties of samples are presented in Table 2.

Table 2. Range And Average Values Of Physiochemical And Biological Properties OF SPRING WATER SAMPLES COLlECTED From KATHMANDU, LALITPUR, TANAHU, NUWAKOT, AND KAVRE DisTRICTS IN $\operatorname{NEPAL}(\mathrm{N}=30)$

\begin{tabular}{|l|c|c|}
\hline & Range & Average \\
\hline Turbidity $(\mathrm{NTU})$ & $1-90$ & $8.3( \pm 18.4)$ \\
\hline Conductivity $(\mu \mathrm{S} / \mathrm{cm})$ & $15-792$ & $217.2( \pm 207.2)$ \\
\hline $\mathrm{pH}$ & $5.9-7.4$ & $6.6( \pm 0.4)$ \\
\hline $\mathrm{Temperature}\left({ }^{\circ} \mathrm{C}\right)$ & $25.5-27.2$ & $26.4( \pm 0.5)$ \\
\hline $\mathrm{Ca}(\mathrm{mg} / \mathrm{l})$ & $2.4-58$ & $21.4( \pm 18.0)$ \\
\hline $\mathrm{Mg}(\mathrm{mg} / \mathrm{l})$ & $0.97-33.5$ & $9.2( \pm 8.4)$ \\
\hline $\mathrm{Bi}-\mathrm{carbonate}(\mathrm{mg} / \mathrm{l})$ & $8-244$ & $75.8( \pm 67.0)$ \\
\hline $\mathrm{SO} 4(\mathrm{mg} / \mathrm{l})$ & $5-88$ & $13.9( \pm 23.3)$ \\
\hline $\mathrm{Na}(\mathrm{mg} / \mathrm{l})$ & $2.6-42.3$ & $12.1( \pm 10.8)$ \\
\hline $\mathrm{NO}(\mathrm{mg} / \mathrm{l})$ & $0.02-117.8$ & $12.1( \pm 24.5)$ \\
\hline $\mathrm{Cl}(\mathrm{mg} / \mathrm{l})$ & $1-36.6$ & $6.6( \pm 9.5)$ \\
\hline $\mathrm{Fe}(\mathrm{mg} / \mathrm{l})$ & $0.01-3.7$ & $0.24( \pm 0.67)$ \\
\hline $\mathrm{As}(\mathrm{mg} / \mathrm{l})$ & $<0.05$ & $4->300$ \\
\hline $\begin{array}{l}\text { Total coliform }(\mathrm{MPN} / 100 \\
\text { ml) }\end{array}$ & $\begin{array}{l}\text { Number in parentheses include } \pm \text { standard deviation. } \\
\text { Source: prepared by the co-authors of this article }\end{array}$
\end{tabular}

The one-way ANOVA test for land use (agriculture, urban, mixed, and vegetation) showed significant land use effects on turbidity, conductivity, $\mathrm{Ca}, \mathrm{Mg}, \mathrm{SO} 4, \mathrm{Na}, \mathrm{NO} 3, \mathrm{Cl}$, and $\mathrm{Fe}$ (Table 3).

TABLE 3. EFFECTS OF LAND USE AND SPRING TYPES ON WATER QUALITY. Ls (LEASt SQUaRes) MEANS DifFERENCE By TUKEY HSD (HONESTly SIGNIFICANT DIFFERENCE), A $=0.05$.

\begin{tabular}{|l|l|l|}
\hline & Land use & Spring type \\
\hline $\mathrm{pH}$ & 0.572 & 0.361 \\
\hline Temp $\left({ }^{\circ} \mathrm{C}\right)$ & 0.328 & 0.114 \\
\hline $\mathrm{TURB}(\mathrm{NTU})$ & 0.011 & 0.385 \\
\hline $\mathrm{COND}(\mu \mathrm{s} / \mathrm{cm})$ & $<0.001$ & 0.094 \\
\hline $\mathrm{Ca}(\mathrm{mg} / \mathrm{L})$ & 0.001 & 0.108 \\
\hline $\mathrm{Mg}(\mathrm{mg} / \mathrm{L})$ & 0.041 & 0.134 \\
\hline $\mathrm{HCO}(\mathrm{mg} / \mathrm{L})$ & 0.092 & 0.169 \\
\hline $\mathrm{SO}_{4}(\mathrm{mg} / \mathrm{L})$ & $<0.001$ & 0.310 \\
\hline $\mathrm{NO}_{3}(\mathrm{mg} / \mathrm{L})$ & $<0.001$ & 0.304 \\
\hline $\mathrm{Na}(\mathrm{mg} / \mathrm{L})$ & 0.002 & 0.048 \\
\hline $\mathrm{Cl}(\mathrm{mg} / \mathrm{L})$ & $<0.001$ & 0.273 \\
\hline
\end{tabular}

\begin{tabular}{|l|l|l|}
\hline Fe $(\mathrm{mg} / \mathrm{L})$ & 0.009 & 0.253 \\
\hline $\begin{array}{l}\text { Total coliform } \\
\text { (CFU/100 mL) }\end{array}$ & 0.381 & 0.493 \\
\hline
\end{tabular}

Source: prepared by the co-authors of this article

However, $\mathrm{pH}$, temperature, $\mathrm{HCO} 3$ and total fecal coliform counts did not show land use effects at 0.05 probability level. In terms of spring type (depression, contact, and fracture (Poudel\&Duex 2017), none of the spring types showed significant effects on water quality parameters except for $\mathrm{Na}(\mathrm{p}$ $\leq 0.05$ ). One possible reason that spring types do not show any effects on water quality is that it may not have been possible to collect the water samples from the springs' origins and therefore spring water composition could have been affected greatly by nearby land use type. However, depression spring type showed significantly higher concentration of $\mathrm{Na}$ than the contact and fracture spring types (Fig. 2).

Interestingly, land use types affected spring water quality differently. While agricultural land use showed significantly higher effect on turbidity, the urban land use type showed significantly higher effect on conductivity, nitrate, sulphate (Fig. 3) and other ions in spring waters.

\section{FIGURE 2. SODIUM CONCENTRATION OF CONTACT, DEPRESSION,} AND FRACTURE SPRING WATERS

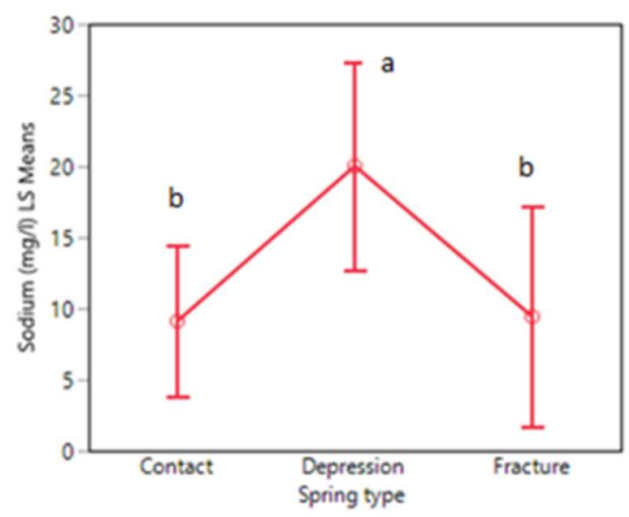

Source: prepared by the co-authors of this article

These results indicate that drinking water sources around agricultural lands should be protected from suspended sediments whereas drinking water sources in urban areas should be protected from dissolved substances. Compared to the World Health Organization Guideline, average values of turbidity (8.3 NTU) and total coliform (263 CFU/100 mL) were higher than the threshold of $5 \mathrm{NTU}$ and zero, respectively, for drinking water. Warner et al. (2008) also have reported total coliform and Escherichia coli bacteria in $94 \%$ and $72 \%$, respectively, of all drinking water samples collected in Kathmandu Valley, suggesting that total coliform pollution of drinking water is a persistent and a widespread problem in Nepal. 
FIGURE 3. EFFECTS OF LAND USE TYPES ON TURBIDITY, CONDUCTIVITY, NITRATE AND SULPHATE CONCENTRATIONS OF SPRING WATERS IN THE MID-HILL REGION OF NEPAL
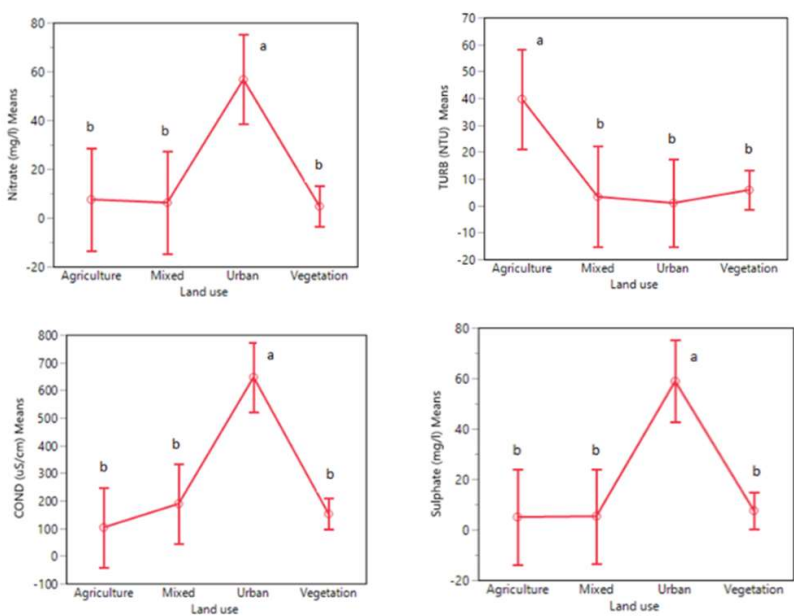

Source: prepared by the co-authors of this article

\section{CONCLUSIONS}

Drinking water security is a major public concern in the midhill region of Nepal. Rapid springs dry ups along with increasing pollution of drinking water sources has threatened the socio-economic viability of the region forcing villagers migrating out leaving their ancestral properties behind. Spring rejuvenation and water conservation practices need to be installed immediately in order to enhance drinking water security and check outmigration and prevent socio-economic disaster in the region. Land use types affect spring water quality differently, therefore, it is important to understand the relationship between land use types and surface water quality and develop water quality monitoring programs, especially for drinking water sources. In order to fully understand the relationship between spring types and water quality, it is important to collect water samples form the locations where the springs originate. Best management practices are needed urgently in regard to turbidity and fecal coliform contamination because these two contaminants exceed the threshold of WHO for drinking water in many parts of the mid-hill region of Nepal. Drinking water security in the midhill region of Nepal is a very challenging issue. In order to tackle this critical issue of drinking water security and safety effectively and enhance the sustainability and environmental quality of the region, comprehensive, multi-sectoral, and grassroots based watershed management and spring rejuvenation initiatives are urgently needed.

\section{Acknowledgement}

We would like to acknowledge Asta-Ja Research and Development Center (Asta-Ja RDC), Kathmandu, Nepal, for coordinating our field activities and helping us by providing a field staff for water quality sampling. Also, we would like to thank all local communities who helped us by directing to the spring water sources and providing us with local information about the drinking water sources.

\section{REFERENCES}

Clesceri, L.S., A.E. Greenberg, and A.D. Eaton., eds. 1998. Standard Methods for the Examination of Water and Wastewater, 20th edition, Washington DC: American Public Health Association.

Corwin, H., K. Eddings, G. Bailey, A. Braun, A. Mann, V. Gomez, H. Heafner, W. Faulk, L. Immel, A. Hingdon, B. Stelly, B.N. Broussard, L. Willis, T.C. Martin, T.J. Mizelle, A.J. Baker, T. Duex, and D.D. Poudel. 2019. Enriching college students through study abroad: a case of Nepal Field Experience, Part 2, ASEJ - Scientific Journal of Bielsko-Biala School of Finance and Law, 23(4) 30-37. DOI 10.5604/01.3001.0013.6850

Government of Nepal, Ministry of Physical Planning and Works. 2005. National Drinking Water Quality Standards, 2062 and National Drinking Water Quality Standard Implementation Guideline,2062 Year: 2063 (BS) Singhadurbar, Kathmandu, Nepal. Available at https://nepalindata.com/resource/national-drinking-water-quality-standards2005-implementation-directives-national-drinking-water-quality-standards2005/ (Accessed on March 5, 2020).

ICIMOD (International Center for Integrated Mountain Development). 2015. Reviving the Drying Springs: Reinforcing social development and economic growth in the midhills of Nepal. Issue Brief, February 2015. Kathmandu, Nepal: ICIMOD.

Merz, J., G. Nakarmi, and R. Weingartner. 2003. Potential solutions to water scarcity in the rural watersheds of Nepal's Middle Mountains. Mountain Research and Development, 23(1):14-18.

Poudel, D.D. and T.W. Duex. 2017. Vanishing springs in Nepalese mountains: Assessment of water sources, farmers' perceptions, and climate change adaptation, Mountain Research and Development, 37(1), 35-46.

Vaidya, S.R. and S. N. Labh. 2017. Determination of physico-chemical parameters and Water Quality Index (WQI) for drinking water available in Kathmandu Valley, Nepal: A review, International Journal of Fisheries and Aquatic Studies, 5(4):188-190.

Warner, N.R., J. Levy, K. Harpp, and F. Farruggia. 2008. Drinking water quality in Nepal's Kathmandu Valley: a survey and assessment of selected controlling site characteristics, Hydrogeology Journal, 16: 321-334. DOI $10.1007 / \mathrm{s} 10040-007-0238-1$ 